\title{
Barriers to the Enforcement of Environmental Law: An Effect of Free Market Domination and Regional Autonomy in Indonesia
}

\author{
Mahoro Jean Claude Geofrey ${ }^{*}$, F.X. Adji Samekto² \\ ${ }^{1}$ School of Law, University of Rwanda, Rwanda; Faculty of Law, Diponegoro University, Indonesia. \\ 2 Faculty of Law, Diponegoro University, Indonesia. \\ * Corresponding author's e-mail: gmahoro88@gmail.com
}

\begin{tabular}{|c|c|}
\hline ARTICLE INFO & ABSTRACT \\
\hline $\begin{array}{l}\text { Keywords: } \\
\text { Biocentrism; Ecocentrism; } \\
\text { Environmental Law; } \\
\text { Globalisation; Regional } \\
\text { Autonomy; Sustainability } \\
\text { How to Cite: } \\
\text { Geofrey, M.J.C and } \\
\text { Samekta, F.X.A. (2021). } \\
\text { "Barriers to the Enfor- } \\
\text { cement of Environmental } \\
\text { Law: An Effect of Free } \\
\text { Market Domination and } \\
\text { Regional Autonomy in } \\
\text { Indonesia" Hasanuddin } \\
\text { Law Review, } 7 \text { (1): 31-45 } \\
\text { DoI: } \\
\text { 10.20956/halrev.v7i1.1896 }\end{array}$ & $\begin{array}{l}\text { This paper discusses different issues relating to the enforcement of } \\
\text { environmental law in Indonesia in the long way of the Indonesian } \\
\text { government to sustainable development. To reach reliable conclusion, } \\
\text { socio-legal approach was employed in this paper. Throughout the work } \\
\text { the researcher analyses environmental philosophies including anthro- } \\
\text { pocentrism, biocentrism and ecocentrism. This phenomenon does not } \\
\text { only pose responsibility to the government but also to private } \\
\text { individuals or companies in their operations in order not to leave } \\
\text { burdens to the shoulders of future generations. This ideology was not } \\
\text { well ensured in the free-market economy and regional autonomy as the } \\
\text { proliferated regulations were not directed to meet the efficient and } \\
\text { equitable environmental principles. Hindrances to the effective } \\
\text { implementation of environmental law, inter alia, the non-envisaged } \\
\text { licensing system in administrative enforcement; ineffective civil } \\
\text { damages towards the environmental losses; and non-reaching } \\
\text { environmental criminal liability. Besides that, the persistent corruption } \\
\text { is anotherimpediment to the effective implementation of environmental } \\
\text { law in Indonesia. }\end{array}$ \\
\hline
\end{tabular}

\section{Introduction}

Indonesia is an archipelago country; its water is 70 per cent of its entire territory; it is wealthy in natural resources such as forests, marines and freshwater, and various species in biodiversity. ${ }^{1}$ Besides, its complex geological history poses a critical environmental concern. For that reason, it needs strong law and regulations concerning environmental protection and management and their effective implementation to preserve all

1 Brad Rippey, "Indonesia Environment and Natural Resource Management in a Time of Transition," The World Bank 54, no. 3 (2001): 32, https://doi.org/10.1001/archsurg.136.2.146. 
components in the ecosystem. However, the effects of regional autonomy led to a plurality in implementation of the environmental law regardless of the Constitutional green provisions. Under the free-market domination, different public utilities have been put in the management of private companies that led to environmental damages in different parts of the country, mainly in Kalimantan and Papua. Also, the sea components were not well ensured as there was no effective maritime policy.

Being rich in biodiversity poses particular attention to Indonesia's environmental laws in the process of economic globalisation. Indonesia has been known to have authoritarian regimes until the Soeharto's fall in 1998. Due to an excessive centralisation of power under Soeharto regime, some outer parts of Indonesia such as Aceh, East Timor, Bali, and West Papua have created strong resistances that could be curbed without devolution of power. The government embarked upon new policies and regulations that put regional autonomy in place. The period has been characterised by democratic leadership that can be considered a 'rise of Indonesia.' Those policies have taken the country to new approaches in its economic structure and its way to sustainable development. Indeed, Indonesia's economy during that time required some reforms not only harmonise its business environment for its nationals but also to attract foreign investors in order to create active competitive industries. In this light, adequate environmental protection and management were vital. However, there was no precise regulation emerging new economic approach and environment. In response to such a situation, the government enacted the Law No 32/2009 concerning environmental protection and management but a proliferation of regulations as a result decentralisation of law-making power to regions, districts and other government tiers has led to ambiguity and disrespect in implementation.

Furthermore, corruption has been persistent in Indonesia and has led to different environmental pollution without the imposition of responsibilities to the polluter companies in different sectors, mainly mining quarrying. The present research intends to highlight hindrances that jeopardised the philosophy of environmental law in Indonesia and to provide suggestions to stakeholders for adopting the concepts of ecocentrism, conservatism, and preservation to ensure better environmental protection and management in Indonesia.

\section{Method}

The current work has employed socio-legal approach. The researcher has explored environmental law and its implementing regulations. Besides, he has used books, journals, and other online materials from both the legal and non-legal scholarships to obtain reliable results and conclusion.

\section{Indonesian Legal Framework on Environment}

The present research has found that despite its consideration to the biodiversity components and other environment objects in the ecosystem, the Law No 32/2009 concerning environmental protection and management has not been well implemented because it experienced a proliferation of regulations as a result of liberalisation, freemarket domination and regional autonomy in the globalisation process. The economic activities did not ensure environmental sustainability, which would be led by various philosophies such as conservation and preservation, biocentrism, and ecocentrism. Instead, human activities such as mining and quarries have endangered the 
environment and did not abide to various recognised environmental principles. Also, corruption was documented to have worsened the situation.

In order to ensure the sustainable development without leaving the gaps between the current and future generations, the global community needs to have green constitutions that ensure citizens the better environment and its sustainability in the process of national economic growth. In this light, the 1945 Constitution states that the proper and healthy environment constitutes a human rights and constitutional rights of every citizen. Under its Article 33 (4), it also sets how the national economy should be organised based on economic democracy upholding the various principle, among others; there are sustainability and environmentally friendliness. ${ }^{2}$ This indicates that the Indonesian constitution has green provisions embracing environmental protection. In the same line, the 2009 environmental law adopted the ecocentrism concept to recognise the right to a healthy environment sustainably. It also governs the land, water, air, forests and wildlife as embarked on by the United Nations through its various legal instruments and programmes such as SDGs. ${ }^{3}$

Moreover, the Government of Indonesia enacted other environmentally friendly laws to ensure a healthy environment and the concept of sustainability. ${ }^{4}$ For example; laws governing industrial and commercial activities impose accountability on those who pose threats on the environment and in various cases, they impose criminal sanctions to any person causing environment distortion. ${ }^{5}$ Notwithstanding the implementation problems raised by the regional autonomy, some laws were documented to be well-written and innovative and providing effective, affordable services like health care and environmental standards. Indonesia's environmental management and protection is a broad aspect governed by many regulations classified into five categories as follow:
a. General Environmental Legislation (GEL);
b. Sector Environmental Legislation (SEL);
c. Ratified Environmental Convention (REC);
d. Provincial Environmental Legislation (PEL); and
e. Local Environmental Legislation (LEL).

Despite such efforts of Indonesia in establishing laws and regulations to ensure the environmental protection and management in its economic growth, none can ignore various environmental harms that kept accelerating in different parts of the country. Indonesia, like any other developing country, is doing much in progress that, in some cases, have negative impacts on the environment. Besides, the globalisation that has not left anyone behind is another factor that posed challenges to developing countries including Indonesia. Nevertheless, the global movement of anthropocentrism has endangered the environment through the exploitation of natural resources without embracing the equilibrium in the ecosystem. Thus, Indonesia was not left by that hit before it adopts biocentrism as a far-reaching philosophy in environmental protection. The following discussion entails more about those challenges that slowed down the implementation of Indonesian environmental law.

\footnotetext{
2 USAID, “Environmental Compliance and Enforcement in Indonesia: Rapid Assessment," 2008, 7.

3 SDGs target 6 ensures the availability and management of sustainable clean water and sanitation for all, while target 15 reflects the protection, restoration and support towards sustainable use of terrestrial ecosystems, management of forests sustainably, fight desertification, and inhibit and reverse land degradation and inhibit loss of biodiversity.

4 Article 30 of the Law No 3 of 2014 on Industrial Affairs.

5 Article 100 (3) of the Law No 20 of 2016 on Marks and Geographical Indications.
} 


\section{A War between Anthropocentrism and Biocentrism}

The global community is experiencing the environmental-related problems that rise the global warming and climate change due to the greenhouse gas emissions resulting from human-made activities. This is due to the compromise of the perpetual and intergenerational environmental management. Strictly, in preserving the biodiversity and the natural value, two environmental philosophies were embraced. Those philosophies, different in their approaches, include anthropocentrism and biocentrism, the former has led environmental challenges facing the global community such as global warming and climate change as it favours the environmental exploitation by humans for the sake of their interests without ensuring its sustainability. Like its other name 'human supremacism,' anthropocentrism considers human supreme to other components of biodiversity in the ecosystem as if other species are there for consumption unethically. ${ }^{6}$ Biocentrism is philosophical ethics about the environment conceptualised by Paul Taylor in his treatise 'Respect for Nature' in 1986 in which he highlighted four basic tenets defining the term 'biocentric outlook' as follow:

(a) Equality of humans and other members of the earth's community of life;

(b) An interdependence between humans and other species;

(c) Life is centred with all organisms in which each is unique in pursuing its own good in its own way;

(d) There is no inherent superiority of humans to other living things.

Taylor emphasised the complex relationship between humans and nature. In his view, humans are not a privilege. As a matter of facts, humans inhabited the earth in a period very shorter than that of other organisms. ${ }^{7}$ Historically, biocentrism is intrinsically rooted in the preaching of Saint Francis of Assis about the respect for nature and later proclaimed to be the patron saint of ecology. Indeed, as the native American tradition ascertains that there is a linkage that binds all nature together, all living beings and natural objects are inherently sacred. In fighting against the continuation of environmental damage, Joshua Rottman has conceptualised biocentrism in two moral aspects; 'harm' and 'purity.'

Concerning the avoidance of harm, he affirms that biocentrism extends human understanding and rights to non-human components in the universe. Indeed, the individuals are not only the ones concerned with environmental harms. Concerning the view of purity or sanctity, nature is a divine creation that would be preserved by humans under their sacred duty. ${ }^{8}$ This point relates to different governmental policies for environmental preservation and management, including the Indonesian Government. Thus, biocentrism is against global capitalism; it reflects the environmental decisions that consider the rights of biotic and abiotic environment not only as useful resources for humans. It is a nature-based, not a human-based philosophy.

By reacting to the global industrialisation and interaction of a man with the nature in the last century, Albert Schweitzer has popularised and promoted the concept of interrelation between plants and animals under the 'reverence for life.' ${ }^{\prime}$ Critically,

\footnotetext{
6 D. Goldsmith and R. Ries, “Biocentric Development Ethics," SASBE2009 - 3rd CIB International Conference on Smart and Sustainable Built Environments, 2009, 1.

7 Bruner, B. "Biocentrism in Environmental Ethics," Source: https://study.com/academy/lesson/ biocentrism-in-environmental-ethics.html. Accessed January 14, 2021.

8 Rottman, J. (2014). "Breaking Down Biocentrism: Two Distinct Forms of Moral Concern for Nature," 2-4, https://doi.org/10.3389/fpsyg.2014.00905.

9 Bruner, "Biocentrism in Environmental Ethics."
} 
conscious choice needs to consider the welfare interests of all living organisms. Biocentrism observes the consequences of biodiversity reduction to the entire ecosystem. Thus, this concept will lead to solutions to the degradation of those resources and environments.

Ecocentrism or biosphere is another philosophy complementing biocentrism. Contrary to biocentrism, which is only concerned with the importance of living beings without consideration of the chemical and geological side of the environment, ecocentrism relies on the importance of the ecosystem as a whole. In light with the environmental treatment, it values the importance of living and non-living components of the ecosystem. This philosophy emphasises the individuals' influence on the ecosystems as a whole. However, the two philosophies are concerned with the environmental wellbeing, they are different on the point that ecocentrism demonstrates the importance of non-living elements by using an ecological study, whereas biocentrism uses living elements of the environment. Sarah Cairoli has given an example of climate change, which is a global concern, whereby biocentrists are concerned with the ways effects of climate change to living things will lead to migration of species and involve a change in wild habitats. Considerably, ecocentrists advocate for the environment with those factors, but they also consider the changes in the abiotic world like a change of sea level and ocean acidity. ${ }^{10}$

In a biocentric point of view, the Indonesian law No 32/2009 concerning environmental protection and management states that the social and economic aspects should assure the of the environment as a whole, safety, capability, welfare and living standards of the present and future generations. In this light, biocentrism or homocentric and ecocentrism are important to the preservation of the environment without leaving burdens to the shoulders of the future generation. Thus, any economic development would ensure the principle of sustainability by considering all the role of all components of biodiversity in the ecosystem. For the case of Indonesia, those concepts remained in texts while they would be implemented with adequate diligence in order to achieve the objectives of the Indonesian constitution and environmental law.

\section{Indonesia in Globalisation}

Globalisation has taken Indonesia further in development on the one hand, but it has accelerated environmental degradation and pollution on the other hand. Despite the environmental law regulating various aspects underpinning the environment, its implementation has not been successful in multiple patterns; thereby, there are potential harms to the environment yet to be tackled.

Globalisation refers to the process of increasing interdependence or creating a network between individuals, firms, countries, and regions. This process entails the free movement of goods, capital, people, services, knowledge, and other aspects that integrates individuals or countries. Internally, the government of Indonesia has adopted the free-market economy where all citizens are invited to the market competition. It deregulated different areas to facilitate investments and liberalise its economy. The government regional autonomy and decentralisation have played a significant role in the economic growth of the country. Indonesia cooperates with other countries; it intends to strengthen the collective endeavour with ASEAN member states to build a

10 Cairoli, Sarah. (2018). “Differences Between Ecocentric \& Biocentric," Sciencing, https://sciencing.com/differences-between-ecocentric-biocentric-18072.html. 
South Asian Zone of peace, freedom, neutrality and prosperity.' It embarked on fostering its cooperation with countries in the Southwest Pacific regions. Besides, it has increased the bilateral investment treaties (BIT) with other countries beyond the region.

Indonesia's long way to the liberalisation of its economy has led to various marketoriented reforms that resulted in free-market domination. It was because of ensuring higher and sustainable exports for strong economic growth. The Indonesian globalisation policy is based on 'an objective assessment of what other countries in East Asia have been able to achieve.'11 The liberalisation of economy intended to make a conducive environment to attract foreign investors. Due to globalisation, Indonesia has given a significant role in the business sector in the development process. As a result of a free-market economy and regional autonomy, the liberalisation of economy, deregulation, and privatisation were the critical elements since the 1980s, although this process has faced barriers due to authoritarian regimes until 1998. Under its globalisation policy, the Indonesian government has made more significant efforts to make its industries competitive at the international level. It ensures effective allocation of resources and access to economic activities to be crucial in the globalisation process as large; it also secures medium and small enterprises.

\subsection{Intraregional Competition}

Under the intraregional competition in Indonesia, local governments' assignments dominated by the free-market economy. Other actors such as civil society and the private sector were invited in the development process. The measurement indicators of efficient use of resources were under the principles of good governance such as responsiveness, inclusiveness, transparency, and accountability. ${ }^{12}$ In order to get economic resources, thereby prosperity, the regions had to compete. Creating a favourable business environment has required much attention. The competitiveness was based on the productive sectors, including infrastructure, regulations regime, and community building. In this respect, the government and civil society have played a big role. Besides, in the so-called 'zero-sum game,' the companies were the first actors in the companies' competitiveness. The companies' management has strongly influenced their productivity and performance, which were the best measurements of competitiveness. Unfortunately, the interregional competition was not environmentally friendly; the environment was exploited as the primary economic resource for prosperity. The stipulated principles were not ensured as environmental pollution, erosion, and other issues like open burns kept accelerating throughout the country.

\subsection{Free-market and Privatisation}

Initially, the free-market economy refers to an economic system under which the citizens and businesses have dominated all decisions and pricing of goods and services. ${ }^{13}$ In order to achieve and maintain national economic prosperity, the law plays a vital role.

11 Soesastro, H. “Globalization: Challenges for Indonesia," 2000, 53, https://www.cipe.org/legacy/ publication-docs/e35_10.pdf.

12 Darmawan, R. "The Practices of Decentralization in Indonesia and Its Implication on Local Competitiveness," Public Administration-Public Governance Study School, 2008, 19-20, https://essay.utwente.nl/ 59282/1/scriptie_R_Darmawan.pdf.

13 Chikozho, C., and Mapedza, E, "Free-Market Economics and Developmental Statism as Political Paradigms: Implications for Water Governance Theory and Practice in Developing Countries," in Freshwater Governance for the 21st Century, Global Issues in Water Policy, ed. E. Karar, vol. 6 (Cham: Springer International Publishing, 2017), 55, https://doi.org/10.1007/978-3-319-43350-9. 
In this light, precise observation is that the measures ascertaining the economic freedoms depend on the law. Among others, 'the free-market measures reflect the ability to start and close an enterprise easily, labour freedom reflected in wage, hour and other restrictions, strong property rights, and freedom from corruption.' 14 In this respect, different laws contribute to the economic advancement, whereas others do not. The fact that pushes laws not to contribute to the economic prosperity is that they are controversial and do not define the concepts of rights, justice, or fairness that they are presumed to embrace as their concern. Considerably, this is defined in the Indonesian constitution under Article 33 (4). Environmentally, some laws are considered essential for economic prosperity, although they are not environmentally friendly.

The free-market economy assumes that the market forces, supply and demand, determine the rightful decision for the government progress. Contrary to the centrally planned economy in which the government is solely a decision-maker on the most aspects of the country's economic activities, the free-market economy allows the consumers to decide on the way they allocate their finances. ${ }^{15}$ In this light, the government is there to protect and stabilise the market from any distortion not to govern all economic aspects. Thus, consumers play a crucial role through their rational decisions in order to optimise their benefits.

The rationale of free-market and privatisation is that the private sector is the inherent dynamism, productivity, and dependence. 16 That is true because the private institutions are superior, in their nature, to the public institutions in delivering goods and services. The market efficiency is their privilege in all ranges of community activity. The free market promotes the expansion of the market economy and monetisation of exchange in social practices. For that reason, the state has a limited power of the socio-economic interventions. Instead, it needs to maximise the freedom of actors through the discussed legal protection and stabilisation of the market.

In different aspects, the free-market economy calls the liberalisation and deregulation of economic transactions internally and across borders. The privatisation of state-owned enterprises and public services are also the criterion of a free-market economy. Besides, it involves the deliberation change of public policy for new governance embracing the decentralisation of national planning and service delivery as well as privatisation and commercialisation of public services, including the supply of water and electricity.

The free market is rooted in seven principles that shape its broad scope of applicability. Individual rights are a principle that concerns with equal rights between the individual about the control and defend their life, liberty, and property and as well the contractual voluntariness exchange. Another principle is the limited government which is concerned limited power of the government whereby it is there only to secure the rights of everyone. Besides, the subsidiarity principle implies that the government authority should exist at the lowest possible level. As other principles are essential in free-market domination, unconstrained order is concerned with competition deregulation as it maximises economic benefit for the society by providing the goods and services at the lowest price. As well, property rights involve the efficiency of private ownership due to its lead to the sustainable use of resources. Finally, the golden rule is the most sanctity

14 Copp, Stephen F. (2008). “The Legal Foundations of Free Markets.” The Legal Foundations of Free Markets, edited by Stephen F. COPP, 19. the Institute of Economic Affairs, 19.

15 Chikozho and Mapedza. Op. Cit., p. 55-56.

16 Ibid. 
principle in free-market domination as it evolves the honest dealing with others for honesty in return. ${ }^{17}$

Free-market and liberalisation waived the Government from some of its responsibilities as maximised the freedom and rights of actors in the economic development process. This has maximised the exploitation of all economic benefit, including environmental without regarding its sustainability. Various principles stipulated in the constitution and environmental law were disregarded, just because the Government set an eye on the outcome instead of the proper process, which left some people in danger.

\subsection{Water Management under Free-Market Domination}

Some developing countries use free-market economy principles to determine the allocation and distribution of water throughout the country, although some public utilities have been struggling with the reforms for implementing the Integrated Water Resources Management (IWRM).18 Those reforms introduced private-sector commercialisation processes aiming at the improvement of the public service delivery across the government departments. That implies the laws of supply and demand for determining the cost of water and strict commitments to making profits. Comprehensively, the implications of these reforms on the efficient and equitable watersupply system are likely to be far-reaching.

The implementations mentioned above were in two lines in which the first one regards the management of water utilities in the urban areas is delegated to the private sector through concession contracts or other agreements. The second line involves the public agencies whereby their management practices are associated with the private sector for both urban and irrigated agriculture. Consequently, an introduction of private-sector management in water utilities involves changes in water rights and licensing regime. Eventually, the water licenses are traded on the open market like any other service based on demand and supply. According to Chikozho and Mapedza, it is the progressive depoliticisation of water governance regime. ${ }^{19}$

The implementation of the IWRM in Indonesia experienced many problems, mainly based on its misleading implementing policies that did not maintain the status of the environment before and after the development of regional land-use plans. According to Fulazzaky, the policies should be established at district, provincial and central government level in order to maintain water run-offs, preserve erosion rate, and 'safeguard the pollutant loads resulting from human activities.' ${ }^{20}$ Besides, the farmers did not ensure the soil conservation principles in their agricultural activities, which led to various water-related issues such as watersheds degradation, water pollution, flood, and soil erosion and sedimentation. Thus, the situation resulted in an imbalance between water supply and demand not only because of the above challenges but also because of the shortages of water due to the monopolisation of water resources by private companies under the Law No. 7/2004 on Water Resources.

17 “Principles of the Free Market," 2009, http://www.freemarketprinciples.com/principles.php.

18 Fulazzaky, Mohamad Ali. (2014). “Challenges of Integrated Water Resources Management in Indonesia." Water, 6(7): 2000-20. https://doi.org/10.3390/w6072000.

19 Chikozho and Mapedza. Op. Cit., p. 57.

20 Fulazzaky, Op. Cit., p. 2012-16. 
The water resource law assigned the management of water resources to private companies, which posed a threat to the water supply system after they started monopolisation. As a result, the Indonesian Constitutional Court annulled the law governing water resources in its decision of February 18, 2015, on the grounds that it was not granting access to clean water to the whole population as it allowed private companies to sell water resources unconstitutionally.21 The law did not ensure that the right to water is a basic right of all citizens and that the control of water resources falls in the government mandate. 22 In the view of the Constitutional Court, a private company would not be granted an exclusive right to water resources. However, it can apply for a license to sell a limited volume of water determined by the government rather than monopolising water resources.

The free-market domination was criticised for being problematic about water tariff in a market-based allocation since water is essential in all life settings. It is likely to deprive the right of the poor people to have access to a safe and reliable water supply.23 Various scholars suggested an option of equity and efficiency in water supply, which implies a small amount allocation of water to poor people at a low price while this implies the riches to pay a higher price. In the same context, the water supply in some countries, an example of Rwanda, the water price depends on the usage volume, the price increases as the usage volume increases. Thus, the rationale is that those who use much water are capable of paying the bill while those who use less are unable, thereby this method is against excessive use of water.

\section{The Concept of Sustainable Development}

The concept of sustainability, however, used interchangeably with sustainable development, refers to the human capacity to live in environmental constraints. Under this concept, all economic activities should respect ecological limits. ${ }^{24}$ In the ecocentrism point of view, all the living and non-living components are essential in the ecosystem, and there is an interdependency between them. Therefore, humans should recognise the importance of biodiversity and ecological components in the ecosystem. This perception gives humans the responsibility to care for the rest of nature for their well-being.

In a biocentric context, by setting aside humans, Stone's observation on other components of nature in the ecosystem such as forests; seas; oceans; and rivers and other environmental natural resources as well as the environment itself, is that they would have rights. ${ }^{25}$ In this light, Achmad Sentosa and Sembiring have interpreted this doctrine by ascertaining that those natural objects have rights, but due to the point that they are inanimate, which poses their inability to enforce their rights, they should be represented. Consequently, under free-market domination, NGOs would play a significant role as guardians of the environment. Henceforth, this strategy would support the

21 Constance Johnson, “Indonesia: Water Law Overturned by Court," Library of Congress, 2015, https://www.loc.gov/law/foreign-news/article/indonesia-water-law-overturned-by-court/.

22 Article 33 (3) of the Indonesian Constitution of 1945.

23 Chikozho and Mapedza, Op. Cit., p. 60-61.

24 Natasha Affolder, "The Legal Concept of Sustainability," Environment in the Courtroom, 2019, 92, https://doi.org/10.2307/j.ctvbd8hx9.11.

${ }^{25}$ Listiyani, Nurul, and M. Yasir Said. (2018). "Political Law on the Environment: The Authority of the Government and Local Government to File Litigation in Law Number 32 Year 2009 on Environmental Protection and Management." Resources 7(4): 1-6. 
enhancement of environmental organisations in implementing the principle of sustainable development. ${ }^{26}$

According to Natasha Affolder, sustainable development is a significant expression of sustainability. The concept of sustainability is against the living in the future generations' expense and natural environment. ${ }^{27}$ Sustainable development is a concept that has been advanced in the Brundtland Report to mean "development that meets the needs of the present generation without compromising the ability of future generations to meet their own needs." 28 A stronger point of the Brundtland Report is that sustainable development integrated sustainability in the development process. This point was reflected in the Rio Declaration under its Principle four (4), which secures environmental protection as an integral part of the development process that cannot be isolated in reaching sustainable development. Besides, the Brundtland Report has raised a crucial part of environmental preservation by merging environment and economic activities.

Sustainable development has embraced different principles as they have been reflected in different environmental conventions. Intergenerational equity is a principle that brings about the exploitation of natural resources in a way that should not set burdens to future generations. Besides, intragenerational equity refers to the distributions of natural resources and justice between nations whereas precautionary principle sets precautional measures that should be taken in case an activity poses a threat to human health or environment although the effects relationship has not fully established. Also, the protection of biodiversity should regard the maintenance of natural ecological life and its management for adaptability to climate change. Lastly, the polluter pays principle recommends that contributors to environmental pollution should be responsible for environmental damage.

\section{Regional Autonomy in Indonesia}

Indonesia experienced an authoritarian regime of Soeharto under which the political powers were centralised in the central government 'pemerintah pusat.' The local governments, including the provinces, districts, cities, and villages, were tasked to implement national policies and directives loyally. ${ }^{29}$ This system was not popular as many provinces have complained against the economic imbalances, excessive military and bureaucratic control and as well the channelling of Indonesia's natural resources to the central government and particularly to Soeharto' family.

Under that regime, different Indonesian outer regions, based on the historical grounds such as culture, ideology and religion, tried to resist the central government. Some of those regions have taken the initiative through their established movements; Papua through the Free Papua Movement -Organisasi Papua Merdeka (OPM), Aceh through the Independent Aceh Movement -Gerakan Aceh Merdeka (GAM). Other regions that wanted to be separated from Indonesia include East Timor, West Papua, and Bali. Those resistances led to different confrontations with military forces that resulted in bloody incidences. For the management of those challenges, the Soeharto regime has been able to curb those resistances. However, upon his fall, it could not be possible to restrain those resistances without further effective strategies. As a result, the Indonesian government

26 Ibid.

27 Affolder, "The Legal Concept of Sustainability."

28 World Commission on Environment and Development, "Brutland Report," 1987.

29 Butt, Simon. (2010). "Regional Autonomy and Legal Disorder: The Proliferation of Local Laws in Indonesia." Sydney Law Review, 32 (2): 177. 
has adopted regional autonomy in order to avoid those threats that could lead to fragmentation and disintegration of the state.

In 1999, after the fall of Soeharto's authoritarian regime, the Indonesian central government had no other option apart from devolving its powers. For that reason, it embarked upon democracy and decentralisation or regional autonomy. Lawmaking powers were entrusted in the local legislatures and executive officials. 30 Simon Butt highlighted the process of regional autonomy that involved decentralisation after the Soeharto regime's fall. Under decentralisation, the law-making power was entrusted in two regional levels: at first, the provinces, and secondly the districts. Under those two levels, there was an authority to issue local policies and enact laws. Provinces and districts were not only assigned to the enactment of laws and issuance of policies but also executive functions. This phenomenon has led to the proliferation of laws in the Indonesian legal system as more than 1000 bodies, individuals, and government tiers had got the lawmaking power. ${ }^{31}$ As there was an increase of provinces, districts, and cities, it has become complicated and uncertain as many local government bodies misdirected the lawmaking power. Most of those laws were unclear, infringing citizens' human rights, imposing excessive fiscal obligations and, compromising the state's international obligations. ${ }^{32}$ Consequently, the phenomenon had effects on the implementation of the environmental law due to various ambiguous regulations and plurality of in implementation at different levels of the Government.

\section{Enforceability of Environmental Law}

The implementation of the Indonesian environmental law No 32 of 2009 is carried out in three forms: administratively, civilly, and criminally. Administratively, the Government applies a licensing system at its different levels whereby for business actors whose activities are likely to have an impact on the environment are required to apply foran environmental permit in a procedure and under certain requirements. If they do not comply with them, they are not licensed. If they are licenced and the supervision latter finds them in violation of environment, their licenses are cancelled, and the administrative sanctions apply.

Moreover, the environmental law is civilly enforceable, where it obliges those who have violatedthe environment to compensations to those whose rights to the environment were infringed based on fault ${ }^{33}$ or strict liability. ${ }^{34}$ By basing on fault, the law sets compensation to anyone whose business activities have resulted in environmental pollution and destruction incurring losses to other people. ${ }^{35}$ For strict liability or absolute responsibility, business actors are presumed to have acted under precautionary and prevention principles to prevent or halt environmental damages. ${ }^{36}$ In the occurrence of damage, they are dictated to pay compensation for the environmental losses not

$30 \quad$ Ibid., p. 179.

31 Currently, the regional autonomy in Indonesia is provided under Law No. 23 of 2014 concerning Regional Autonomy as amended by Law No. 9 of 2015.

32 Butt, S., Op.Cit., p. 178."

33 Article 87 of the environmental law No 32 of 2009.

34 "Strict Liability, Jurus Ampuh Hukum Lingkungan Menjerat Korporasi Tanpa Buktikan Unsur Kesalahan," ICL, 2018, https://icel.or.id/strict-liability-jurus-ampuh-hukum-lingkungan-menjerat-korporasi-tanpabuktikan-unsur-kesalahan/.

35 Article 87 of the environmental law No 32 of 2009.

36 Imamulhadi. (2013). "Perkembangan Prinsip Strict Liability Dan Precautionary Dalam Penyelesaian Sengketa Lingkungan Hidup." Mimbar Hukum, 25(3): 417-32. 
necessarily basing on fault. ${ }^{37}$ The enforcement of criminal sanctions is the last resort in the implementation of environmental law in Indonesia. ${ }^{38}$ It is applied to individuals as well as business entities committing environmental offenses. Also, those sanctions extend to their administrators involved in such offenses.

Despite the above stipulations, the implementation of the environmental law No $32 / 2009$ has always been hard due to different issues. After the government undertook the globalisation process, it was obliged to liberalise its economy for mainly foreign investors. In addition, regional autonomy and decentralisation of law-making power have led to a proliferation of regulations in various fields as well as in environmental respect. Apart from that, the free-market domination has set out environmental responsibilities to private sectors, which resulted in different problems. Investors always need to maximise their benefits by minimising the cost, which is a compromise to the concept of sustainability. In this light, various cases regarding environmental pollution from investors companies in Indonesia can justify the scenario.

The Indonesian environmental law reflects the intergenerational equity in environmental protection and management, which does not compromise the future generation. It is clear in its Article one whereby it recalls different aspects that should be regarded in the development process. Under its Article two, it lists 14 principles under which the environmental protection and management should be implemented, namely state responsibility; conservation and sustainability; harmony and equilibrium; integration; benefit; prudence; justice; ecoregion; biological diversity; polluter pays; participation; local wisdom; good governance; and regional autonomy.

The government and its decentralised entities have put many implementing regulations into place, but regulation No. 27 of 2012 regarding environmental permits is the one that raised different issues in the mining sector. Since 2015, the government enhanced the protection and sustainability of its forestry and peatland. ${ }^{39}$ Besides, the government extended its moratoriums on 'forestry concessions in specific forestry and peatlands areas.' It enacted the Presidential Regulation No. 57 of 2016 amending Presidential Regulation No. 71 of 2014 regarding the Protection and Management of Peatland Ecosystems. ${ }^{40}$ This regulation did not only prohibit any clearing of new land before the implementation of zoning system for the protection and cultivation of peatland ecosystems but also the drainage and fire in the peatlands.

Concerning the United Nations Framework Convention on Climate Change, Indonesia implements the related reforms by combating deforestation to reduce greenhouse gas emissions. Those reforms took into account the conservation, sustainable management of forests, and enhancement of forest carbon stocks. Apart from those efforts, the Indonesian Supreme Court was empowered with 15 specialised courts under the partnership with the European Union in order to handle the environmental cases.

37 Bandung District Court Decision No 49/Pdt.G/2003/PN BDG of September 4, 2003 on compensation claim case on the landslide of Mount Mandalawangi, Kadungora Subdistrict, Garut District (the Mandalawangi Decision).

38 Article 100 of the environmental law No 32 of 2009 provides a criminal sanction of three (3) years of imprisonment at maximum and a fine of Rp3,000,000,000 (three billion rupiah) at the maximum to anyone violating the quality standard of waste water, emission or nuisance. Also, the law imposes criminal sanctions to corporate entities and their leaders in case they commit the environmental crimes as stipulated in article 116, 117 and 118. Besides, those entities suffer additional penalties and disciplinary measures of different forms.

39 Dawborn, David, and Matthew Goerke. (2012). “Major Projects: Environmental Risks in Indonesia: Overview, Practical Law." Thomas Reuters Practical Law, 1-23.

40 Ibid. 
Despite the above move in environmental protection, the open forest burns related to palm oil plantation, deforestation, peatlands degradation and trash burn in agriculture have led to air pollution. For example, the forest burn in Sumatra and Kalimantan has caused what was called the 'South Asian haze crisis' in the nearby country regions and neighboring countries and resulted in deaths and respiratory disorders. This crisis compelled the government to take immediate action that led to the suspension of different projects in order to take significant attention to forestry and peatland protection and sustainability. ${ }^{41}$

Concerning water pollution and other risks related to mining and oil, and gas activities, the soil erosion increased pollution of the sea waters due to upland deforestation. The use of pesticides and fertilisers has abetted toxicity in the water supply chain and led to the accumulation of algae in the riverbeds. The environmental risks have accelerated the challenges on coastal commercial areas' activities. Another big issue associated with water pollution is the contamination of water supply as a result of mining and oil, and gas activities. An incidence of Buyat Bay, Sulawesi can justify the situation in this regard. Besides, several volcanic eruptions and other volcanic-related problems like the mud volcano in Sidoarjo, East Java that led to the environmental crisis in Indonesia. ${ }^{42}$

The implementation of environmental law was not only declined by the proliferation of regulations, mainly related to its implementation, which was in contradiction with the entire national legal framework and the international obligations of the state but also with corruption. According to Jean-Jacques Dethier, ${ }^{43}$ the ADIPURA program for urban cleanliness, that was successful in environmental management in the Indonesian urban cities since 1986, was tainted by corruption in 2010. At the moment, an award deserving the winning city in the successful implementation of ADIPURA program that takes place on the annually International Environmental day on June 5, was given to Bekasi, a city known to have many polluters for long time due to numerous major industrial enterprises, and Citarum River, which is a highly polluted river.

\section{Conclusion}

Indonesia experienced a challenging legal system after devolution of law-making power to provinces, cities, and other government tiers under regional autonomy. However, it has settled different problems that could lead to the fragmentation of the state after the Soeharto regime. Environmental law, like other laws, confronted the plurality in their implementations based on the proliferated regulations from decentralised entities. Besides, the globalisation process that implied liberalisation and privatisation has compromised the principle of sustainability in national economic growth. Disrespect of those numerous regulations led to environmental damages in various fields, including water treatment and mining investment sectors. Also, the effects of the persistent corruption in Indonesia led to violations of the environment mostly by companies, that were entrusted in its preservation, as they were not held liable for their environmental harms.

In a nutshell, to address environmental issues in Indonesia requires to take action at all levels with inclusiveness, and all measures would embrace the concept of environmental conservation and preservation as well as sustainability. Besides, keeping in mind the

\footnotetext{
41 Ibid.

42 Ibid.

43 Dethier, Jean-Jacques. (2017). “Trash, Cities, and Politics: Urban Environmental Problems in Indonesia." Southeast Asia Program Publications at Cornell University, 103: 83.
} 
philosophy of biocentrism and ecocentrism in the country, economic growth will be the sole solution for it does not leave any component behind the biodiversity. Human beings, various species and inanimate objects of the universe would be understood in the sense that they have rights as they all contribute to the equilibrium of the ecosystem. Therefore, anyone of the stakeholders, including the Government and private companies, would consider sustainability in their functioning. In addition, they would abide by the environmental principles adopted at both international and national levels for preserving and conserving the environment. However, the Government of Indonesia would take its prevailing role to empower the legal framework as far as environmental protection and management are concerned. Also, it would build a strong network in environmental control that reports all potential environmental harms to the respective authority. Hopefully, this will lead to the effective implementation of environmental law.

\section{References}

Bruner, Bob. "Biocentrism in Environmental Ethics." study.com. Accessed January 14, 2021. https://study.com/academy/lesson/biocentrism-in-environmental-ethics.html.

Butt, Simon. (2010). "Regional Autonomy and Legal Disorder: The Proliferation of Local Laws in Indonesia." Sydney Law Review, 32 (2): 177.

Cairoli, Sarah. "Differences Between Ecocentric \& Biocentric." Sciencing, 2018. https://sciencing.com/differences-between-ecocentric-biocentric-18072.html.

Chikozho, Claudious, and Everisto Mapedza. (2017). "Free-Market Economics and Developmental Statism as Political Paradigms: Implications for Water Governance Theory and Practice in Developing Countries." In Freshwater Governance for the 21st Century, Global Issues in Water Policy, edited by E. Karar, 6:55. Cham: Springer International Publishing. https://doi.org/10.1007/978-3-319-43350-9.

Copp, Stephen F. (2008). "The Legal Foundations of Free Markets." In The Legal Foundations of Free Markets, edited by Stephen F. COPP, 19. the Institute of Economic Affairs.

Darmawan, R. (2008). “The Practices of Decentralization in Indonesia and Its Implication on Local Competitiveness." Public Administration-Public Governance Study School, 19-20. https://essay.utwente.nl/59282/1/scriptie_R_Darmawan.pdf.

Dawborn, David, and Matthew Goerke. (2012). "Major Projects: Environmental Risks in Indonesia: Overview, Practical Law." Thomas Reuters Practical Law, 1-23.

Dethier, Jean-Jacques. (2017). "Trash, Cities, and Politics: Urban Environmental Problems in Indonesia." Southeast Asia Program Publications at Cornell University, 103: 83.

Fulazzaky, Mohamad Ali. (2014). “Challenges of Integrated Water Resources Management in Indonesia." Water (Switzerland) 6(7): 2000-20. https://doi.org/10.3390/w6072000.

Goldsmith, D., and R. Ries. (2009). "Biocentric Development Ethics." SASBE2009 - 3rd CIB International Conference on Smart and Sustainable Built Environments, 1.

ICL. (2018). "Strict Liability, Jurus Ampuh Hukum Lingkungan Menjerat Korporasi Tanpa Buktikan Unsur Kesalahan." https://icel.or.id/strict-liability-jurus-ampuhhukum-lingkungan-menjerat-korporasi-tanpa-buktikan-unsur-kesalahan/.

Imamulhadi. (2013). "Perkembangan Prinsip Strict Liability Dan Precautionary Dalam Penyelesaian Sengketa Lingkungan Hidup." Mimbar Hukum, 25(3): 417-32.

Ingelson, A. (Ed.). (2019). Environment in the Courtroom. Calgary, Alberta: University of 
Calgary Press. Retrieved April 2, 2021, from $\underline{h t t p: / / w w w . j s t o r . o r g / s t a b l e / j . c t v b d 8 h x 9}$ Johnson, Constance. (2015). “Indonesia: Water Law Overturned by Court." Library of Congress.

Listiyani, Nurul, and M. Yasir Said. (2018). “Political Law on the Environment: The Authority of the Government and Local Government to File Litigation in Law Number 32 Year 2009 on Environmental Protection and Management." Resources 7(4): 1-6.

National Park Service. "Theodore Roosevelt and Conservation," 2017. https://www.nps.gov/thro/learn/historyculture/theodore-roosevelt-and-conservation.htm.

Rippey, Brad. (2001). "Indonesia Environment and Natural Resource Management in a Time of Transition." The World Bank, 54(3): 32. https://doi.org/10.1001/ archsurg.136.2.146.

USAID. "Environmental Compliance and Enforcement in Indonesia: Rapid Assessment," 2008, 7. 